\title{
PARAGUAYANS IN THE FOREST SECTOR OF THE ARGENTINE ECONOMY
}

\author{
C.A. Pizarro \\ University of Buenos Aires \\ Av. San Martin 4453 - C1417DSE Buenos Aires, Argentina
}

\begin{abstract}
This paper analyses the participation of Paraguayan migrant men in the forestry labor market of the Paraná River Delta. Although forestry is not the principal activity in which these migrants work in Argentina, this case is relevant to show the way in which discrimination mechanisms based on ethno-national stereotypes make cheap foreign labor available. At first, based on the last Argentine Population Census, we show that Paraguayans are the most important migrant group in Argentina. Second, we describe the socio-demographic features of the Paraguayan population in the Paraná River Delta, and compare them with the trends in other places of destination in Argentina. Finally, based on our ethnographic research developed in the Delta, we analyze the labor hierarchies of forestry production; local discrimination discourses against Paraguayans; migratory networks that make these laborers available; and their working and living conditions. We argue that the expansion and profitability of forestry production in the Paraná River Delta is enabled by this segmented labor market that assigns migrant young men to the lowest positions of the labor hierarchy.
\end{abstract}

Key words: Paraguayan migrants, labor market, Argentina

\section{Paraguayan migration to Argentina}

Paraguayan is nowadays the most important migrant group in Argentina, followed by the Bolivian and the Peruvian ones. These three regional migrations are part of the wider migratory system in the Southern Cone of South-America within which Argentina is the main country of reception (Pizarro, 2016).

Paraguayan migrations to Argentina have taken place even before the conformation of both countries at mid $19^{\text {th }}$ Century. Paraguayan population in Argentina has always been less than $1,5 \%$ of the total population in the country, and more than the $8 \%$ of the total in Paraguay (Bruno, 2013).

In 2010, according to the last Argentine Population Census, it was $1,37 \%$ of the total population of Argentina; 66,22\% of the foreign population in Argentina; 44,23\% of the total population born in neighbor countries in Argentina; and 8,54\% of the total population of Paraguay. The annual growth rate of Paraguayan population in Argentina between Census periods shows that these percentages have steadily grown since 1991 (Table 1).

Between 1869 and 1947, Paraguayans have mainly migrated to the North-East Argentine Provinces located in the border with Paraguay, where they worked in agriculture. Buenos Aires City (capital of Argentina) and in the Province of Buenos Aires became the most important places of destination at mid $20^{\text {th }}$ Century, though Paraguayans have also been registered there in since 1869. Their concentration in these areas has increased 


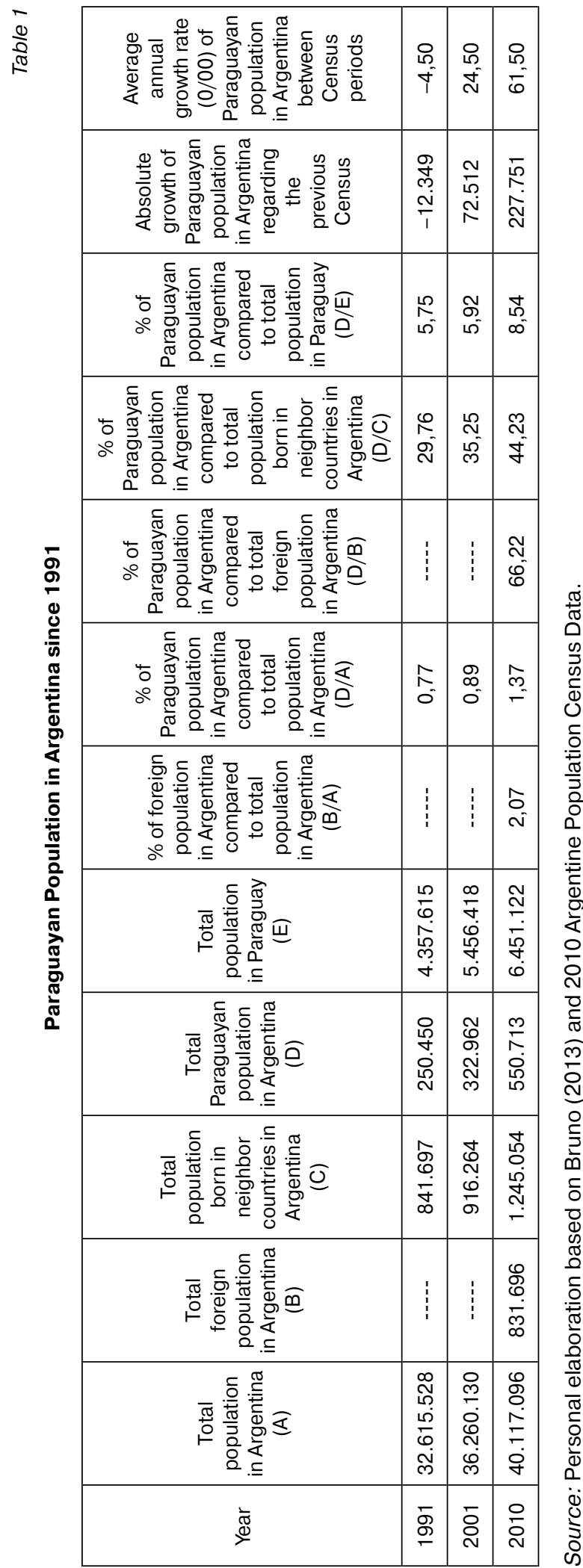


and, in 2010, 85,9\% of the Paraguayan population in Argentina lived there. Besides, Paraguayan population in North-East Argentina is gentrified in contrast with that in the City and the Province of Buenos Aires, where it concentrates within the economically active age range (Bruno, 2013).

Table 2 shows that, since 1991, the main places of destination of Paraguayans have been the North-East Provinces, the City of Buenos Aires and Province of Buenos Aires which includes several districts that are part of the Metropolis of the City of Buenos Aires (Table 2).

Table 2

Distribution of the Paraguayan Population in Argentina in 1991, 2001 and 2010 (in percentages)

\begin{tabular}{|c|c|c|c|c|}
\hline \multirow{2}{*}{\multicolumn{2}{|c|}{ Jurisdictions }} & \multicolumn{3}{|c|}{ Year } \\
\hline & & 1991 & 2001 & 2010 \\
\hline & Buenos Aires City & 11,60 & 14,50 & 14,60 \\
\hline \multirow{3}{*}{ Province of Buenos Aires } & $\begin{array}{l}\text { Districts which are part of the Metropolitan } \\
\text { Area of Buenos Aires City }\end{array}$ & 53,90 & 58,80 & 60,80 \\
\hline & $\begin{array}{l}\text { Districts which are not part of the Metropolitan } \\
\text { Area of Buenos Aires City }\end{array}$ & 5,30 & 7,10 & 10,60 \\
\hline & Total in the Province of Buenos Aires & 59,20 & 65,90 & 71,40 \\
\hline \multicolumn{2}{|r|}{ North-East Provinces } & 25,70 & 16,60 & 9,90 \\
\hline \multicolumn{2}{|r|}{ Rest of Argentina } & 3,70 & 3,20 & 4,20 \\
\hline
\end{tabular}

Source: Personal elaboration based on Bruno (2013) and 2010 Argentine Population Census Data.

The change in the distribution of the Paraguayan population in Argentina and the increase in the amount of exiles and labor emigrants in Paraguay are correlated with the Paraguayan civil war of 1947; the beginning of a long-standing dictatorship in 1954; and the aggravation of a socio-economic crisis that produced the impoverishment of many country people at Paraguay (Bruno, 2013; Halpern, 2009). Although the majority of Paraguayan migrants in Argentina come from peasant rural or peri-urban areas, most of them live in urban areas.

According to Argentine Population Census 2010,75,39\% of Paraguayan migrants live in the Metropolitan Area of Buenos Aires City. Their main economic activities are construction for men (31,4\% of Paraguayan migrant working men in Argentina), and domestic services for women (58\% of Paraguayan migrant working women). Feminization is significant: the sex ratio of the Paraguayan population in Argentina is 79,7 (Bruno, 2013).

Construction and domestic services are gender and ethno-national segmented labor markets where Paraguayan men and women are stereotyped as the most suitable workers (Bruno, 2013; del Águila, 2014; Pacceca, Courtis, 2008; Vargas, 2005; among others). This mechanism of race/cultural discrimination naturalizes the ethnicization of the production relationships, since Paraguayans are assigned to the lowest positions of labor hierarchies (Pizarro, 2016; Pizarro and Straccia, 2015).

On the one hand, Paraguayans -together with Bolivians, Peruvians, Chinese and Koreans- are considered non desired migrants according to Argentine socio-cultural classifications of the otherness. On the other hand, long-standing kinship social networks help them to economically and emotionally undergo the first stage of migration; and to find a job. 


\section{Paraguayan migrants in a rural area of the province of buenos aires}

As said above, the main features of Paraguayan population in Argentina are: concentration in urban areas (mainly in the Metropolitan Area of Buenos Aires City); feminization; and domestic services and construction as the main economic activities of women and men. Thus, the participation of Paraguayan migrants in an agricultural labor market in the Province of Buenos Aires is outstanding.

According to our research in an area of the Paraná River Delta located in that Province, most of the forestry workers are Paraguayan men. The labor market demand has been steadily supplied by these migrants since the 1990s (Pizarro and Straccia, 2015; Pizarro, 2016).

The forestry plantations where they work are located in a territory administrated by two sub-provincial jurisdictions: the Districts of Campana and San Fernando. The sociodemographic features of the Paraguayan population in both Districts contrast with the general trends of the whole Paraguayan population in Argentina.

Paraguayans are the 2,62\% of the total population in the District of San Fernando. This percentage is similar to that of the Province of Buenos Aires $(2,67 \%)$, and it stands between those of Argentina (1,37\%) and of Buenos Aires City (3,20\%) (Table 3). This might be due to two facts, among others. First, this District is part of the Metropolitan Area of the City of Buenos Aires. Second, its urbanized area is remarkably populated; in contrast with the Delta area of the District, which is less populated although it is quite bigger. Many of the Paraguayans in this District work in urban areas, the same as in the City of Buenos Aires and its Metropolitan Area.

On the contrary, that percentage of the Paraguayan population of the total population in the District of Campana is considerably lower: $0,87 \%$ (Table 3). This might be due to the following reasons, among others. This District is not part of the Metropolitan Area of the City of Buenos Aires and that the demands of construction and domestic service labor markets are not so high. Besides, it provides fewer social services than the Metropolitan Area of the City of Buenos Aires, and its way of life is not so attractive to migrants wishing to live in a modern and European-like city, as Buenos Aires is thought of by many Latin American migrants.

Table 3

Main Socio-Demographic Features of Paraguayan Population in the Districts of Campana and San Fernando

\begin{tabular}{|l|c|c|c|}
\hline \multicolumn{1}{|c|}{ Jurisdictions } & $\begin{array}{c}\text { \% of Paraguayan } \\
\text { population compared } \\
\text { with the total population } \\
\text { of the jurisdiction }\end{array}$ & $\begin{array}{c}\text { \% of Paraguayan } \\
\text { population compared } \\
\text { with the total foreign } \\
\text { population in the } \\
\text { jurisdiction }\end{array}$ & $\begin{array}{c}\text { Paraguayan } \\
\text { population sex } \\
\text { ratio }\end{array}$ \\
\hline Argentina & 1,37 & 66,22 & 79,72 \\
\hline Buenos Aires City & 3,20 & 21,04 & 65,37 \\
\hline Province of Buenos Aires & 2,67 & 41,69 & 81,56 \\
\hline District of Campana & 0,87 & 29,91 & 83,68 \\
\hline District of San Fernando & 2,62 & 31,44 & 82,99 \\
\hline
\end{tabular}

${ }^{1}$ Forestry plantations are located in part of each district.

Source: Personal elaboration based on 2010 Argentine Population Census Data 
Sex ratio in both Districts is higher than in other places of destination in Argentina where feminization is remarkable: 83,68 in Campana and 82,99 in San Fernando (Table 3).

Unfortunately, the statistical areas of the Argentine Population Census within the Districts do not coincide with the areas comprised by the Delta islands in neither of both districts. Nevertheless, the distribution of Paraguayans in the urban ${ }^{1}$, rural $^{2}$ and rural dispersed $^{3}$ areas, show the relevance of those living in the latter (Table 4).

These areas refer to the Delta islands since there are not any villages or towns, houses are considerably separated of each other, and there are very few inhabitants per $\mathrm{km}^{2}$. Since there are not any other areas in neither of both Districts with such a landscape, it can be inferred that data regarding rural dispersed population refers to people living in those islands.

Table 4

Paraguayan Population in or outside Urban and Rural Areas by Jurisdiction

\begin{tabular}{|l|c|c|c|c|c|c|c|}
\hline \multirow{2}{*}{$\begin{array}{c}\text { Political-Territorial } \\
\text { Jurisdictions }\end{array}$} & Urban & Rural & $\begin{array}{c}\text { Rural } \\
\text { Dispersed }\end{array}$ & Total & $\begin{array}{c}\text { \% Urban } \\
\text { Population }\end{array}$ & $\begin{array}{c}\text { \% Rural } \\
\text { Dispersed } \\
\text { Population }\end{array}$ & $\begin{array}{c}\text { \% Rural } \\
\text { Population }\end{array}$ \\
\hline Province of Buenos Aires & 387.570 & 1.007 & 4.120 & 392.697 & 98,69 & 1,05 & 0,26 \\
\hline District of San Fernando & 3.723 & 0 & 224 & 3.947 & 94,32 & 5,68 & 0,00 \\
\hline District or Campana & 661 & 49 & 89 & 799 & 82,73 & 11,14 & 6,13 \\
\hline
\end{tabular}

Source: Personal elaboration based on 2010 Argentine Population Census Data.

It is interesting to note the gender and age structure of the census designated rural dispersed Paraguayan population in both Districts. The sex ratio in the District of Campana is 178,13, and 261,29 in the District of San Fernando. Besides, 88,76\% of the Paraguayans in the former district are within the economically active range, while $84,82 \%$ in the latter. Thus, it can be assumed that forestry is the main economic activity of Paraguayan men in the Delta islands comprised in both jurisdictions.

\section{Paraguayans in the forestry labor market in the Paraná River Delta}

Willow and poplar wood for paper industry, pellets and furniture in the Paraná River Delta is mainly produced in the islands of the Districts of Campana and San Fernando. This agricultural activity has steadily expanded since the 1950s and is nowadays the main one. There are four important forestry companies which own very large plantations, and monopolize the transport and trading of the production of less capitalized local forestry farmers (Pizarro, 2016; Pizarro, Straccia, 2015).

One of the reasons why forestry has become a mono-activity is the existence of a segmented labor market. During the 1970s and 1980s, workers used to be local people and domestic migrants coming from nearby Provinces. Paraguayan young men have gradually substituted them since the 1990s.

These foreign migrants are hired in the lowest positions of labor hierarchies which do not require specific qualifications. Middle positions are mainly occupied by domestic

1 This category comprises people living in places with more than 2.500 inhabitants.

2 This category comprises people living in places with less than 2.500 inhabitants.

3 This category comprises people living outside census designated urban and rural places. 
migrants who handle agricultural machinery. Argentine professionals, former non qualified workers who have accumulated experience and social capital, or farmers' relatives generally supply upper positions such as foremen, managers and executives.

According to local common sense, Paraguayan workers are the most suitable for hard, force requiring tasks such as handling machetes and chainsaws used to prune, harvest and plant trees. It is believed that they have a remarkable "working culture" due to their peasant background and that they are strong and resistant because of their "indigenous blood". These race/culture biased arguments naturalize xenophobic discrimination and justify precarious working and living conditions.

Before 2004, the Argentine Migration Law was extremely restrictive and did not recognize migrants' rights. Moreover, those defined as illegal foreigners were subject to be deported. At that time, many Paraguayans accepted low wages, informal contracts and precarious working and living conditions because they were undocumented. But nowadays many still do the same; even when Argentine regulations do not criminalize irregular migrants any more, proceedings to regularize migrant status are not so difficult, migrants coming from neighboring countries are not required visas or working permits, and the exchange rate between Argentine and Paraguayan money has not been so profitable for them between 2001 and 2015.

Paraguayan men still accept informal work contracts and low wages because of several reasons. Poverty in their places of origin is usually extreme. Therefore, a low wage in Argentina might make a great difference in the social reproduction of the relatives at their homeland. Besides, as many people born in peasant areas of other Latin American countries, they idealize Argentine modern and European way of life. Finally, not every Paraguayan migrates to find a job; some also want to save money in order to pay their studies or to visit those acquaintances that had migrated before, among other motivations.

Migratory networks might explain the continuous migration of Paraguayan men to the Paraná River Delta. Many are called by a relative or a friend who gives them the money to buy the tickets -or even goes to their homeland to pick them up- and helps them to find a job.

For instance, one of the Paraguayan forestry workers we interviewed during our research had been called by a cousin approximately in 1990, and was hired in the plantation where his relative worked. He kept on working seasonally even when his cousin quitted. $\mathrm{He}$ came and went across the border for several years, returning periodically to the rural village where he was born.

He fall in love with a women there, but kept on traveling to work in forestry in the Paran River Delta. After some years he convinced her of getting married and they went together to the islands. Even though she did not like the place at first, they settled down and had three children. He continued working in forestry but she was not able to find a job because there are scarce jobs for women and she had to bring up her children.

He began bringing relatives and friends from his village at Paraguay when his boss needed seasonal workers. Other farmers asked him to do the same for them, since he was known to be reliable and they believed that the men he brought were very good laborers.

He was paid for the work of the teams he managed, and distributed the earnings among the laborers while he kept a percentage for himself. This deal, together with his own wage as a permanent laborer, has enabled him to save enough money during the last years to buy a four-wheel truck and some land in Paraguay. In February, 2016, his brother, six 
brothers in law, and many other men from his homeland were part of his several teams working in different plantations.

Paraguayan laborers' living conditions differ depending on the size of the plantation where they are hired. Those who work in forestry companies generally live in relatively well equipped houses and they have formal work contracts that guarantee their labor rights, though they are not provided health insurance. It must be remarked that this was not the case some years ago. The amelioration of working and living conditions in these companies might be due to two facts. On the one hand, state inspections of labor conditions as well as fiscal obligations have increased during the last ten years. On the other hand, the companies are nowadays wishful to achieve certain standards to certify Good Forestry Practices, which include the good quality of working and living conditions.

Nevertheless, ethno-national discrimination still occurs even in those companies that may fulfill those requirements. For instance, in one of the forestry companies we visited, workers live in different kind of houses according not only to their labor position but also to their nationality. The best ones are for local people or domestic migrants that work as foremen or handle machinery, while Paraguayans live in older, smaller and not so comfortable houses.

Regarding the living conditions of those Paraguayans working in small forestry farms, their bosses usually lend them old, precarious and small houses as part of the work contract.

This is also the case in forestry companies, as it turns out of the following example. At the beginning of 2016, during an extraordinary flow that periodically occur in the islands, the only families that had to be evacuated were those of two Paraguayans who work in forestry companies. The houses were in very bad conditions and had no protections against flood, even though both companies wish to certificate Good Forestry Practices.

Farmers are fond of Paraguayans because they think that there would be no forestry activity if it was not for their eagerness to work hard. Nevertheless, these labor migrants are stereotyped as criminals and dangerous. This might be related to Argentine common sense prejudices not only during the 1990s, when they were considered illegal migrants, but also nowadays as they are associated to drugs and people trafficking.

But there is another reason that must be also taken into account. The Paraná River Delta has been considered an inhospitable and isolated area until recent years. It was thought to be a very suitable hiding place for either native or migrant malefactors escaping from justice. Local people say that during the 1990s illegal Paraguayans did not work in urban areas because it was too risky, while there were almost no state controls in the Delta because of its isolation.

Nowadays, local people still discriminate against Paraguayans arguing that they are criminals even though Argentine Migratory Law 2004 does not criminalize undocumented migrants. Nevertheless, forestry companies and farmers still hire them, since they provide very cheap working force.

\section{Conclusions}

Paraguayan migration is nowadays the most important in Argentina. It has taken place since at least mid $19^{\text {th }}$ Century, and has steadily increased during the last 25 years. Paraguayans tend to concentrate in urban areas, mainly in the Metropolitan Area of Buenos Aires City; women migrants predominate over men; women mainly work in 
domestic services and men in construction. Although forestry production is not their principal economic activity, their participation in that labor market in the Paraná River Delta is an interesting case that shows the way in which discrimination mechanisms based on ethno-national stereotypes make cheap foreign labor available.

Based in the analysis of the Argentine Population Census 2010, we have showed that the socio-demographic features of the Paraguayan population that live in the Districts of Campana and San Fernando, where the forestry area of the Paraná River Delta is located, are quite different from the main trends at the national level. As much as the available statistical data allow, we have argued that the majority of Paraguayan people in these Districts are men that live and work in the forestry area.

Finally, our ethnographic research results show that local discourses against Paraguayan workers assign them certain cultural and biological attributes that naturalize race discrimination and justify their precarious working and living conditions. We explained how migration networks contribute to exploitation by providing laborers that accept low wages, harsh tasks and informal working conditions. We also described the precarious dwellings which are lent to Paraguayan workers by the owners of the forestry companies and farms where they are hired.

Briefly, we have argued that the forestry labor market in the islands of the Paraná River Delta comprised in the Districts of Campana and San Fernando of the Province of Buenos Aires is segmented by ethno-national discrimination, and assigns Paraguayan men to the lowest positions of labor hierarchies. In this way, these migrants are the cheap working force that enables the expansion and profitability of forestry production in the area.

\section{REFERENCES}

Bruno, S. El proceso migratorio paraguayo hacia argentina: evolución histórica, dinámica asociativa y caracterización socio-demográfica y laboral // Migrantes paraguayos en Argentina: Población, instituciones y discursos. Cuadernos Migratorios. Editorial de la OIM. 2013. No. 4. P. 9-56.

Del Águila, A. Etnicidad y clase social entre migrantes paraguayos en la industria de la construcción del Área Metropolitana de Buenos Aires // Trabajo y Sociedad. 2014. No. 23. P. 439-463.

Halpern, G. Etnicidad, inmigración y política. Representaciones y cultura política de exiliados paraguayos en Argentina. Buenos Aires: Editorial Prometeo, 2009.

Herrera Lima, F. Vidas itinerantes en un espacio laboral transnacional. México D.F.: Editorial de la Universidad Autónoma de México, 2005.

Pacceca, M.I., Courtis, C. Inmigración Contemporánea//Argentina: Dinámica y políticas. Santiago de Chile: Editorial del Centro Latinoamericano y Caribeño de Demografía - División de Población. 2008.

Pizarro, C. Trabajadores paraguayos en la producción forestal del Delta Inferior del río Paraná. In: Aparicio, S. y Benencia, R. (ed.) De migrantes y asentados. Trabajo estacional en el agro argentino. Buenos Aires: Editorial CICCUS, 2016. P. 112-136.

Pizarro, C. y Straccia, P. "Hay mucho paraguayo acá”. Nuevas formas de organización laboral en la producción forestal del Delta Inferior del río Paraná. Paper presented at IX Jornadas Interdisciplinarias de Estudios Agrarios y Agroindustriales Argentinos y Latinoamericanos. Buenos Aires. 2015.

Vargas, Patricia. Bolivianos, paraguayos y argentinos en la obra: identidades étnico-nacionales entre los trabajadores de la construcción. Buenos Aires: Editorial Antropofagia, 2005.

(C) Pizarro C., 2017 
Acknowledgements:

The study was conducted with the support from the University of Buenos Aires grant, Project 20020130100147BA.

Article history:

Received: 6 December 2016

Revised: 16 January 2017

Accepted: 28 January 2017

For citation:

Pizarro C. (2017) Paraguayans in the forest sector of the Argentine economy. RUDN Journal of Economics, 25 (1), 137-145.

Bio note:

Pizarro C., Professor at the School of Agriculture of the University of Buenos Aires. Contact information: e-mail: pizarro.cynthia@gmail.com

\title{
ПАРАГВАЙЦЫ В ЛЕСНОЙ ОТРАСЛИ ЭКОНОМИКИ АРГЕНТИНЫ
}

\author{
С. Пизарро \\ Университет Буэнос-Айреса \\ Проспект Сан-Мартин 4453 - C1417DSE, Буэнос-Айрес, Аргентина
}

\begin{abstract}
В статье анализируется участие парагвайских мужчин-мигрантов на рынке труда в лесном секторе дельты реки Парана. Хотя лесное хозяйство не является основным видом деятельности, в котором работают эти мигранты в Аргентине, этот случай имеет отношение к тому, чтобы показать, каким образом механизмы дискриминации, основанные на этнонациональных стереотипах, делают дешевой иностранную рабочую силу. Основываясь на данных последней переписи населения Аргентины установлено, что парагвайцы являются наиболее важной группой мигрантов в Аргентине. На основе этнографических исследований проанализирована структура миграционных потоков, выявлены проблемы дискриминации мигрантов. Исследование доказало, что расширение и рентабельность лесного хозяйства в дельте реки Парана обеспечивается благодаря сегментированному рынку труда, основанному на дискриминации трудовых мигрантов на местном рынке труда.
\end{abstract}

Ключевые слова: парагвайские мигранты, рынок труда, Аргентина

\section{История статьи:}

Дата поступления в редакцию: 6 декабря 2016

Дата принятия к печати: 28 января 2017

\section{Для цитирования:}

Пизарро С. Парагвайцы в лесной отрасли экономики Аргентины // Вестник Российского университета дружбы народов. Серия: Экономика. 2017. Т. 25. № 1. С. 137-145.

Сведения об авторе:

Пизарро Синтия Александра, профессор Школы агрономии Университета Буэнос Айреса. Контактная информация: e-mail: pizarro.cynthia@gmail.com 